\title{
High-Temperature Semi-Dry and Sweet Low Alcohol Wine-Making Using Immobilized Kefir Culture
}

\author{
Anastasios Nikolaou (D) and Yiannis Kourkoutas *(D) \\ Laboratory of Applied Microbiology \& Biotechnology, Department of Molecular Biology \& Genetics, \\ Democritus University of Thrace, 68100 Alexandroupolis, Greece; anikol@mbg.duth.gr \\ * Correspondence: ikourkou@mbg.duth.gr; Tel.: +30-25510-30633
}

check for updates

Citation: Nikolaou, A.; Kourkoutas, Y. High-Temperature Semi-Dry and Sweet Low Alcohol Wine-Making Using Immobilized Kefir Culture. Fermentation 2021, 7, 45. https:// doi.org/10.3390/fermentation7020045

Received: 31 December 2020

Accepted: 22 March 2021

Published: 25 March 2021

Publisher's Note: MDPI stays neutral with regard to jurisdictional claims in published maps and institutional affiliations.

Copyright: (c) 2021 by the authors. Licensee MDPI, Basel, Switzerland. This article is an open access article distributed under the terms and conditions of the Creative Commons Attribution (CC BY) license (https:// creativecommons.org/licenses/by/ $4.0 /)$.

\begin{abstract}
Low alcohol wines $(\leq 10.5 \%$ vol) represent novel wine products steadily gaining the commercial market interest. Considering the technological advancements of immobilized systems in association with the drastic reduction of industrial operational costs in high-temperature winemaking in regions with tropical climate or hot summer periods, the aim of the present study was to assess the fermentation efficiency of both wet and freeze-dried immobilized kefir culture on natural supports in low alcohol wine production at high temperatures $\left(>30^{\circ} \mathrm{C}\right)$. Immobilized kefir culture was evaluated and compared to free cells in repeated batch fermentations for 3 months, indicating high operational stability, and found suitable for simultaneous alcoholic and malolactic low alcohol wine fermentation at temperatures up to $45^{\circ} \mathrm{C}$. High ethanol productivity [up to $55.3 \mathrm{~g} /(\mathrm{Ld})$ ] and malic acid conversion rates (up to $71.6 \%$ ), which could be adopted by the industrial sector, were recorded. Principal Component Analysis (PCA) revealed that the state of the cells rather than the nature of kefir culture affected significantly the content of minor volatiles determined by Head Space Solid-Phase Microextraction (HS-SPME) Gas Chromatography-Mass Spectrometry (GC/MS) analysis. Notably, all new products were of high quality and approved by the sensory panel. The results suggested a high industrial potential of the proposed technology in semi-dry low alcohol wine-making at $37^{\circ} \mathrm{C}$ and in developing novel wine products with a sweet (liquoreux) character at $45^{\circ} \mathrm{C}$.
\end{abstract}

Keywords: low alcohol wine; kefir culture; Immobilization; high-temperature fermentations; PCRDGGE analysis; volatiles

\section{Introduction}

Low alcohol wines ( $\leq 10.5 \% \mathrm{vol}$ ) represent novel products steadily gaining the consumers' interest over the past few years, due to multiple reasons, including social, lifestyle, and economic motives [1]. Based on the alcoholic strength, low alcohol wines can be divided into lower alcohol (up to $10.5 \% v / v$ ), reduced alcohol (up to 6.5\% $v / v$ ), low alcohol $(0.5-1.2 \% v / v)$ or dealcoholised $(<0.5 \% v / v)$ wines, although this distinction may vary greatly between countries [2,3]. However, in order to achieve low alcohol concentrations, standard practice is based on pre-fermentation vineyard strategies aiming in low sugar content (decreasing the leaf-area-to-fruit-mass ratio, application of growth regulators, selection of the harvest date) or various post-fermentation physicochemical treatments (membrane systems, vacuum or osmotic distillation, spinning cone technology and supercritical carbon dioxide extraction) [4], thus affecting negatively the wine characteristics [2].

Malolactic (ML) wine fermentation usually commences under normal conditions by malolactic bacteria (Oenococcus oeni, Pediococcus sp., and Lactobacillus sp.) naturally located on grapes or the wooden vats used for wine storage [5]. ML fermentation is known to lead to acidity reduction, bacteriological stabilization, modification of sensory attributes, etc. [6]. However, implications, such as fermentation delays or even failures may appear and thus application of mixed cultures (yeasts and malolactic bacteria) for simultaneous alcoholic and malolactic fermentation is usually suggested [7]. 
The use of microbial cultures in wet form, however, is not always compatible with the modern industrial and commercial needs and, therefore, drying methods are usually applied. Indeed, freeze-dried cultures remain increasingly preferred to wet cultures in bioprocesses, due to advantages associated with protection against microbial contamination, longer preservation times, easy to handle products during storage, etc. [8]. Similarly, immobilization technology is suggested in industrial applications, as it results in maintenance of cell viability during freeze-drying, processing, and storage [9] and is linked with high operational stability, enhancement of cell viability, improvement of fermentation productivity, cell control and cell recycling, application of continuous system configurations, improved final product quality, etc. [10,11].

"Kefir" is a traditional Russian drink, initially consumed in Caucasus Mountains centuries ago that can be manufactured by different types of milk (sheep, cow, goat, etc.) and is nowadays globally considered a healthy product with high nutritional value [12]. It is produced by kefir culture, a symbiotic mixture of microorganisms, including yeasts (Kluyveromyces, Candida, Saccharomyces, and Pichia), lactic acid bacteria (Lactobacillus, Lactococcus, and Leuconostoc species), and occasionally, acetic acid bacteria [13] that co-exist and are responsible for an acid-alcoholic fermentation [14]. Kefir culture is considered an advantageous starter culture in the food industry and has been applied in various food and drink fermentations (bread, cheese, milk, juice, etc.) [12]. Immobilized kefir cells on delignified cellulosic material (DCM), apple pieces, and grape skins have been previously successfully used in wine and cider fermentations at a wide temperature range $[6,15]$. Recently, freeze-dried immobilized kefir culture was assessed in low alcohol wine and cider production $[8,16]$. In industrial wine production, ambient temperature fermentations are very often used, but application of cooler temperatures may be advantageous to the product quality [17]. White, rosé, and fruit wines (especially aromatic varieties) require lower temperature fermentations $\left(10-20^{\circ} \mathrm{C}\right)$, in order to preserve the fruity aromas. Red wines on the other hand, require higher temperature fermentation (up to $28^{\circ} \mathrm{C}$ ) to achieve the desirable color and tannin extraction from the grape skins $[17,18]$. High fermentation temperatures $\left(>30^{\circ} \mathrm{C}\right)$ may result in high fermentation rates, increased productivity, and reduction of production expenses $[15,16,19,20]$, but inactivation of most industrial yeasts is, however, a major drawback [19]. Therefore, it would be of great economical and industrial interest to investigate wine-making at temperatures $>30{ }^{\circ} \mathrm{C}$ in many regions worldwide, resulting in limitation of cooling systems requirement and drastic reduction of operational costs (mostly in regions with tropical climate or in many countries with hot summer periods) [6], whilst leading to novel wine products development.

The aim of the study was to investigate the suitability of both wet and freeze-dried immobilized kefir culture in low alcohol wine production at high temperatures $\left(>30^{\circ} \mathrm{C}\right)$. Important enological parameters indicating the efficiency of immobilized kefir culture in simultaneous alcoholic and ML fermentations during low alcohol wine-making in high temperatures are presented.

\section{Materials and Methods}

\subsection{Immobilization of Kefir Culture and Fermentation Medium}

Kefir culture was isolated from a traditional dairy kefir drink (Caucasus, Armenia) [8]. Wet kefir culture was initially grown and stored on synthetic medium $[4 \% w / v$ glucose (Fluka, Buchs, Switzerland), 0.5\% $w / v \mathrm{MgSO}_{4} 7 \mathrm{H}_{2} \mathrm{O}$ (Merck, Darmstadt, Germany), 0.1\% $w / v\left(\mathrm{NH}_{4}\right)_{2} \mathrm{SO}_{4}$ (Merck), $0.1 \% w / v \mathrm{KH}_{2} \mathrm{PO}_{4}$ (Fluka) and $0.4 \% w / v$ yeast extract (Fluka)] [15]. Immobilization on natural supports (DCM, apple pieces, grape skins) was performed, as recently described [6]. In brief, $1420 \mathrm{~g}$ of apples pieces, $480 \mathrm{~g}$ of DCM, and $500 \mathrm{~g}$ of grape skins, were mixed separately with $1 \mathrm{~L}$ of synthetic immobilization medium $[12 \% w / v$ glucose (Fluka), 0.5\% w/v $\mathrm{MgSO}_{4} 7 \mathrm{H}_{2} \mathrm{O}$ (Merck), $0.1 \% w / v\left(\mathrm{NH}_{4}\right)_{2} \mathrm{SO}_{4}$ (Merck), $0.1 \% w / v$ $\mathrm{KH}_{2} \mathrm{PO}_{4}$ (Fluka) and $0.4 \% \mathrm{w} / v$ yeast extract (Fluka)] and $1 \mathrm{~L}$ of kefir culture [12] and left to ferment overnight at $30{ }^{\circ} \mathrm{C}$. The fermented liquid was then decanted and the immobilized cells were washed with sterile $\frac{1}{4}$ strength Ringer's solution. 
Concentrated grape musts of Roditis and Savatiano varieties were provided by "B.G. Spiliopoulos S.A." (Patras, Greece) and "Georga's Family" (Spata, Greece) wine companies, respectively [8]. Prior to use, both musts were diluted with sterilized deionized water to a final $\sim 10 \pm 0.5^{\circ}$ Be density, mixed by $1: 1$ ratio, in order to exploit both cultivars' aromas $(\sim 170 \pm 8.5 \mathrm{~g} / \mathrm{L}$ sugars, $3.2 \pm 0.2 \mathrm{~g} / \mathrm{L}$ malic acid, total acidity $5.0 \pm 0.5 \mathrm{~g}$ tartaric acid/L, $\mathrm{pH} 4.5 \pm 0.1)$, and used in repeated batch fermentations.

\subsection{Freeze-Drying of Kefir Culture}

Free and immobilized kefir culture was subjected to freeze-drying on a BenchTop Pro (Virtis, SP Scientific, Warminster, PA, USA), as recently described [8]. In brief, kefir culture (free or immobilized) was initially frozen to $-80^{\circ} \mathrm{C}$ for $20 \mathrm{~h}$ and subsequently freeze-dried at $\sim 30-35 \mathrm{~Pa}$ for $24 \mathrm{~h}$ (the condenser temperature was fixed at $-101^{\circ} \mathrm{C}$ ). Of note, immobilized cells on apple pieces were freeze-dried for $72 \mathrm{~h}$, due to the porous nature of the support.

\subsection{Repeated Batch Fermentations}

Repeated batch fermentations (250 mL each) of diluted grape must mixture were conducted using either wet or rehydrated freeze-dried free $(10 \mathrm{~g} / \mathrm{L})$ or immobilized kefir culture on natural supports (1420 g of immobilized kefir cells on apple pieces/L, $480 \mathrm{~g}$ of immobilized kefir culture on DCM/L or $500 \mathrm{~g}$ immobilized kefir culture on grape skins/L), as recently described [8]. In brief, 3 repeated batch fermentations were initially carried out at $30^{\circ} \mathrm{C}$ and served as control samples (data not shown) [8]. Then, five repeated batch fermentations were performed at $37{ }^{\circ} \mathrm{C}$ and 2 at $45^{\circ} \mathrm{C}$ using either wet or freeze-dried free or immobilized cells in batch bioreactors of 0.5 or $1 \mathrm{~L}$. Grape must mixture $\approx 10 \pm 0.5^{\circ} \mathrm{Be}$ was used to wash both free and immobilized cells after the end of each fermentation and before the next fermentation run.

\subsection{Molecular Analysis}

PCR-DGGE analysis was applied on both wet and freeze-dried kefir culture after fermentations on each temperature set were completed [15]. Sequencing of the DGGE fragments and data analysis were performed, as described previously [21]. In brief, bacterial DNA was amplified with primers V3f (5' CCT ACG GGA GGC AGC AG $\left.3^{\prime}\right)$ and V3r $\left(5^{\prime}\right.$ ATT ACC GCG GCT GCT GG $\left.3^{\prime}\right)$, while primers NL1 (5' GCC ATA TCA ATA AGC GGA GGA AAA G3') and LS2 (5' ATT CCC AAA CAA CTC GAC TC $3^{\prime}$ ) were used for eucaryotes. DGGE analysis was conducted using an INGENYphorU DGGE system (Ingeny International B.V., Goes, The Netherlands) in a 0.8-mm-thick polyacrylamide gel with a denaturant gradient 40 to $60 \%$ [100\% corresponded to $7 \mathrm{M}$ urea and $40 \%(w / v)$ formamide] under constant voltage of $120 \mathrm{~V}, 100 \mathrm{~mA}$ for $8 \mathrm{~h}$ at $60{ }^{\circ} \mathrm{C}$. Followed the electrophoresis, the gels were scanned with a Molecular Imager FX fluorescent imager (Bio-Rad Laboratories Inc., Hercules, CA, USA).

DGGE fragments excised from the gel, were left to diffuse overnight in $100 \mu \mathrm{L}$ of sterile water at $4{ }^{\circ} \mathrm{C}$. Ten microliters of the eluted DNA from each band were reamplified with primers V3f and V3r for bacteria and NL1 and LS2 for eukaryotes. Nucleospin Extract II Kit (Macherey-Nagel, Düren, Germany) was used for PCR products purification, according to the manufacturer's protocol. Sequencing was performed by VBC-Biotech (Wien, Austria). Searches in the GenBank with the BLASTn program were used to determine the closest known relatives of the partial rRNA sequences obtained. DGGE analysis was performed at least twice.

\subsection{Chemical Analyses}

The $\mathrm{pH}$, total acidity, and volatile acidity were determined as previously described [15]. Ethanol, glycerol, residual sugars, and organic acid content were determined by HPLC analysis [Shimadzu chromatography system (Shimadzu Corp., Duisburg, Germany)] using 
standard curves based on standard solutions $\left(R^{2}>0.99\right)$ [15]. Fermentation parameters were calculated as follows.

Ethanol productivity: $g$ of ethanol produced per day per liter of liquid volume of bioreactor.

Conversion: (Initial sugar conc. - Residual sugar conc.)/Initial sugar conc. ${ }^{*} 100$.

Ethanol production yield: $g$ of ethanol produced per $g$ of sugars utilized.

Malic acid conversion: (Initial malic acid conc. - Residual malic acid conc.)/Initial malic acid conc. ${ }^{*} 100$.

Concentration of major volatiles was determined by Gas Chromatography (MASTER GC Fast Gas Chromatograph (DANI Instruments S.p.a., Milan, Italy)) and calculated using standard curves prepared by standard solutions $\left(R^{2}>0.99\right)$ [15]. Minor volatiles were determined by Headspace Solid-Phase Microextraction (HS-SPME) Gas Chromatography-Mass Spectrometry (GC/MS) analysis (6890N GC, 5973NetworkedMS MSD (Agilent Technologies, Santa Clara, CA, USA)) and semi-quantified using 4-methyl-2-pentanol as internal standard [6].

\subsection{Preliminary Sensory Analysis}

New wine products were assessed for their quality characteristics using locally approved protocols in our laboratory [8]. A mixed panel (males and females) of twelve wine enthusiasts, not involved in the project and thus not biased, was subjected to a blind randomized test and asked to provide scores on a 0-5 scale (0: unacceptable, 5 : wonderful) regarding aroma (fruity, winelike, spirituous, yeasty, piquant) and taste attributes (sweetness, sourness, bitterness), as well as aftertaste, body, and overall quality. All samples were served on site (in order to avoid volatile diffusion) in a colored glass under low light at $12-15^{\circ} \mathrm{C}$ and the tasters were asked to rinse their palates with water and eat a cracker between samples.

\subsection{Statistical Analysis}

All data was analyzed for statistical significance by 3-way analysis of variance (with the exception of HS-SPME GC/MS results that were analyzed by 2-way analysis). The state of the cells (wet or freeze-dried), the nature of kefir culture (free or immobilized) and the fermentation temperature were considered as factors. The Bonferroni correction was used to identify significant differences $(p<0.05)$ among results. Statistical significance at $p<0.05$, coefficients and ANOVA tables were computed by Statistica v.12.0 (Stat Soft Inc., Tulsa, OK, USA).

Principal Component Analysis was computed by XLSTAT 2015.1 (Addinsoft, Paris, France) [15].

\section{Results and Discussion}

\subsection{Repeated Batch Fermentations}

Kefir culture was initially immobilized on natural supports and freeze-drying, a nonselective treatment widely used in food industry, was applied. The suitability of both wet and freeze-dried kefir culture in high-temperature wine-making $\left(>30^{\circ} \mathrm{C}\right)$ was then tested in simultaneous alcoholic and ML repeated batch fermentations. Despite the positive impact of low temperature fermentations $\left(<20^{\circ} \mathrm{C}\right)$ in wine quality [17], fermentations at high temperatures $\left(30-45^{\circ} \mathrm{C}\right)$ were selected based on warm climate conditions of many countries during grape harvesting period. Repeated batch fermentations at $30^{\circ} \mathrm{C}$ served as control samples (data not shown). Although low alcohol wine production using both wet and freeze-dried immobilized kefir culture on DCM, apple pieces, and grape skins was recently proposed [8], low alcohol wine-making at high temperatures $\left(>30^{\circ} \mathrm{C}\right)$ was not investigated. Fermentation kinetic data and other important parameters are presented in Tables 1 and 2. 


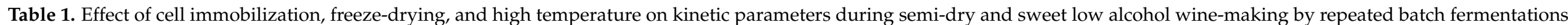
using kefir culture.

\begin{tabular}{|c|c|c|c|c|c|c|c|c|c|c|c|c|c|c|c|c|}
\hline $\begin{array}{l}\text { Nature of Kefir } \\
\text { Culture }\end{array}$ & ${ }^{\circ} \mathrm{C}$ & $\mathbf{N}^{\circ}$ & \multicolumn{2}{|c|}{ Fermentation Time (h) } & \multicolumn{2}{|c|}{$\begin{array}{c}\text { Ethanol Concentration } \\
(\% \text { vol })\end{array}$} & \multicolumn{2}{|c|}{ Glycerol (g/L) } & \multicolumn{2}{|c|}{ Residual Sugars (g/L) } & \multicolumn{2}{|c|}{$\begin{array}{c}\text { Ethanol Productivity } \\
\text { [g/(Ld)] }\end{array}$} & \multicolumn{2}{|c|}{$\begin{array}{c}\text { Ethanol Production } \\
\text { Yield }\end{array}$} & \multicolumn{2}{|c|}{ Conversion (\%) } \\
\hline \multicolumn{3}{|c|}{ State of the Cells: } & W & Fd & W & Fd & W & Fd & W & Fd & W & $\mathbf{F d}$ & W & $\mathbf{F d}$ & W & $\mathbf{F d}$ \\
\hline \multirow{2}{*}{ Free cells } & 37 & 5 & 91-208 & $215-380$ & $7.4-9.6$ & $7.8-8.8$ & $6.6-8.1$ & $4.6-7.2$ & $11.2-15.2$ & $11.8-19.5$ & $7.9-20.0$ & $3.9-7.8$ & $0.37-0.46$ & $0.41-0.44$ & $91.5-93.4$ & $88.5-93.0$ \\
\hline & 45 & 2 & 48 & 96 & $1.0-1.3$ & $0.8-1.0$ & $2.0-2.5$ & $1.8-2.2$ & $93.1-100.0$ & $100.6-110.0$ & $4.0-5.3$ & $1.6-1.9$ & $0.11-0.14$ & 0.11 & $41.2-45.2$ & $35.3-40.8$ \\
\hline apple pieces & 45 & 2 & 48 & $24-48$ & $1.8-3.2$ & $0.8-2.2$ & $2.2-3.6$ & $2.1-3.3$ & $78.4-79.8$ & $89.1-104.5$ & $7.0-12.8$ & $3.0-17.4$ & $0.16-0.28$ & $0.09-0.21$ & $53.0-53.9$ & $38.5-47.6$ \\
\hline Immob. cells on & 37 & 5 & $36-72$ & $86-120$ & $8.1-10.5$ & $9.3-10.5$ & $5.4-7.8$ & $6.7-7.3$ & $0.6-11.8$ & $0.5-10.9$ & $23.5-55.3$ & $14.7-23.1$ & $0.40-0.47$ & $0.45-0.47$ & $93.1-99.7$ & $93.6-99.7$ \\
\hline DCM & 45 & 2 & $24-48$ & $24-48$ & $1.5-5.2$ & $1.4-2.9$ & $2.2-4.8$ & $2.4-4.0$ & $60.3-78.4$ & $82.6-92.6$ & $5.8-40.8$ & $5.5-22.9$ & $0.13-0.37$ & $0.14-0.26$ & $53.9-64.5$ & $45.5-51.4$ \\
\hline Immob. cells on & 37 & 5 & $69-92$ & $120-260$ & $7.0-10.5$ & $6.7-10.0$ & $5.2-7.6$ & $5.8-6.7$ & $0.7-12.5$ & $5.4-59.1$ & $14.5-28.6$ & $5.3-14.5$ & $0.35-0.47$ & $0.42-0.47$ & $92.6-99.6$ & $65.2-96.8$ \\
\hline grape skins & 45 & 2 & 48 & 72 & $1.0-4.5$ & $0.9-3.2$ & $2.3-5.0$ & $2.9-4.7$ & $60.1-108.3$ & $101.2-110.5$ & $3.9-17.6$ & $2.4-8.4$ & $0.13-0.32$ & $0.12-0.37$ & $36.3-64.7$ & $35.0-40.5$ \\
\hline \multicolumn{17}{|c|}{$F$-values } \\
\hline \multicolumn{3}{|c|}{$\begin{array}{l}\text { State of the cells } \\
\text { Nature of kefir culture }\end{array}$} & \multicolumn{2}{|c|}{$\begin{array}{l}18.95^{* *} \\
14.62 * *\end{array}$} & \multirow{2}{*}{\multicolumn{2}{|c|}{$\begin{array}{l}3.46^{*} \\
410.95^{* *}\end{array}$}} & \multirow{2}{*}{\multicolumn{2}{|c|}{$198.64 * *$}} & \multirow{2}{*}{\multicolumn{2}{|c|}{$\begin{array}{l}4.50^{* *} \\
595.86^{* *}\end{array}$}} & \multirow{2}{*}{\multicolumn{2}{|c|}{$9.06 *$}} & \multirow{2}{*}{\multicolumn{2}{|c|}{$222.19^{* *}$}} & & \\
\hline \multicolumn{3}{|c|}{ Fermentation temperature } & \multicolumn{2}{|c|}{$\begin{array}{l}14.62 \\
63.48 * *\end{array}$} & & & & & & & & & & & \multicolumn{2}{|c|}{594.86 ** } \\
\hline \multicolumn{3}{|c|}{ All interactions } & \multicolumn{2}{|c|}{1.03} & \multicolumn{2}{|c|}{0.17} & \multicolumn{2}{|c|}{0.63} & \multicolumn{2}{|c|}{0.54} & \multicolumn{2}{|c|}{0.06} & \multicolumn{2}{|c|}{0.16} & & \\
\hline
\end{tabular}

$\mathrm{N}^{\circ}$ : Number of repeated fermentation batches; W: Wet cells, Fd: Freeze-dried cells; ${ }^{*} p<0.05,{ }^{* *} p<0.01$.

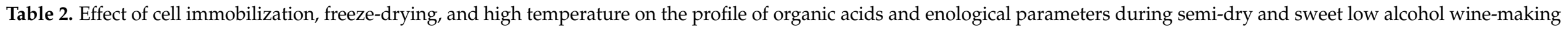
by repeated batch fermentations using kefir culture.

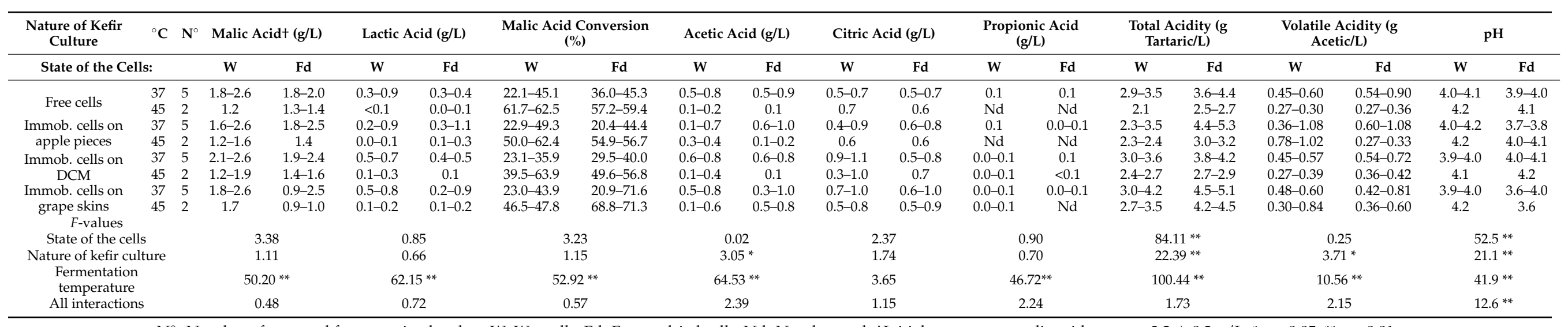

$\mathrm{N}^{\circ}$ : Number of repeated fermentation batches; W: Wet cells, Fd: Freeze-dried cells; Nd: Not detected; +Initial grape must malic acid content: $3.2 \pm 0.2 \mathrm{~g} / \mathrm{L} ;{ }^{*} p<0.05,{ }^{* *} p<0.01$. 
Ethanol productivity, fermentation time, residual sugars, sugar conversion, $\mathrm{pH}$ and total acidity were significantly $(p<0.05)$ affected by the nature of kefir culture (free or immobilized), the state of the cells (wet or freeze-dried) and the fermentation temperature, while strong interactions $(p<0.05)$ were noted. Ethanol concentration, ethanol production yield, volatile acidity and acetic acid content were significantly $(p<0.05)$ affected by the nature of the culture and the fermentation temperature, while strong interactions $(p<0.05)$ were observed between all factors. In contrast, malic acid concentration and malic acid conversion, lactic acid, propionic acid and glycerol concentration were affected significantly $(p<0.05)$ only by the fermentation temperature. No significant differences were observed in citric acid content.

Free or immobilized kefir cells were evaluated regarding their fermentation efficiency in repeated batch fermentations for a period of 3 months. Wine-making at $37^{\circ} \mathrm{C}$ using wet or freeze-dried immobilized kefir culture on DCM resulted in significantly $(p<0.05)$ lower fermentation times compared to fermentations with free cells, in accordance to our previous studies $[15,16]$. Ethanol concentration ranged $6.7-10.5 \%(v / v)$ and higher mean values were noted in fermentations with wet and freeze-dried cells when immobilized kefir culture on DCM was used, although not significantly. Higher ethanol productivities [up to $55.3 \mathrm{~g} /(\mathrm{Ld})$ ] were noted in fermentations with immobilized cells (both wet and freezedried) at $37^{\circ} \mathrm{C}$ in comparison to free cells [19], although not significantly in all cases, but in levels similar or greater than usually noticed in industrial fermentations [19,22]. Importantly, as repeated batch fermentations proceeded, fermentation times, ethanol production and fermentation kinetic data were improved for all freeze-dried kefir cells, indicating cell adaptation $[19,23,24]$, despite the high fermentation temperature $\left(37^{\circ} \mathrm{C}\right)[16]$, and a high operational stability that could be adopted by the wine sector for low alcohol wine production [2]. On the contrary, at $45^{\circ} \mathrm{C}$, significantly $(p<0.05)$ higher residual sugars and significantly $(p<0.05)$ lower conversion values were documented compared to fermentations carried out at $37^{\circ} \mathrm{C}$ (especially after the first batch fermentation) [15], probably due to "yeast stress" induced by the high temperature [19,25]. Nevertheless, ethanol productivity values observed at $45^{\circ} \mathrm{C}$ were still several times higher than usually observed in traditional wine-making $[19,22]$. Remarkably, fermentations with immobilized kefir cells (both wet and freeze-dried) proved effective $[19,26]$ as higher amounts of ethanol (up to $5.2 \% \mathrm{vol}$ when wet immobilized cells on DCM were used) were produced compared to thermotolerant strains previously tested [26]. Interestingly, the alcohol content produced at $45^{\circ} \mathrm{C}$ is considered adequate for manufacture of low alcohol wine types [1,2,27], while the high residual sugars content is considered proper for providing a sweet character $[17,26,28,29]$.

Glycerol content ranged from 1.8-8.1 g/L, depending on the fermentation temperature, but remained well within the values usually produced by yeasts in table wines [30]. Specifically, fermentations at $37^{\circ} \mathrm{C}$ resulted in significantly $(p<0.05)$ higher glycerol concentration, possibly contributing to the "sweetness", by lowering the wine astringency and smoothing of the taste [31].

The kefir culture maintained ML activity during the high-temperature fermentations $[6,15,16]$, which was enhanced by the immobilization process [32]. Hence, malic acid conversion values up to $71.6 \%$ were recorded in fermentations with freeze-dried immobilized culture on grape skins at $37^{\circ} \mathrm{C}$, while similar high malic degradation values were previously reported [6,33-36]. Acetic acid is known to add complexity to wine taste and odor when found at low levels (up to $0.3 \mathrm{~g} / \mathrm{L}$ ) [17], but may also exceed $2.0 \mathrm{~g} / \mathrm{L}$ in certain wine types, thus adding to high volatile acidity and providing their special character [30]. However, it never exceeded $1.0 \mathrm{~g} / \mathrm{L}$ in the wines produced, in accordance to previously published results on wine fermentations with wet free or immobilized kefir cells [6]. Moreover, total and volatile acidity also ranged in values typical for wines $[6,28,37]$. Increased $\mathrm{pH}$ values $(4.5 \pm 0.1)$ were recorded in the initial diluted grape must mixture, but within typical levels for musts extracted through successive press fractions [38]. In the repeated batch fermentations however, $\mathrm{pH}$ ranged in levels previously reported in wine-making using wet immobilized kefir cells [6]. 


\subsection{Monitoring of Kefir Culture Biodiversity}

The kefir culture used was isolated by home-made traditional kefir drink originated in Armenia and belongs to the microbial collection of the Laboratory of Applied Microbiology and Biotechnology, Department of Molecular Biology and Genetics, Democritus University of Thrace (Alexandroupolis, Greece). Its microbial composition was recently investigated with DNA Next Generation Sequencing [8]. The predominant populations identified were Kluyveromyces marxianus / Kluyveromyces lactis and Saccharomyces cerevisiae (among other sub-dominant yeasts), and Lactobacillus kefiri (among other sub-dominant Lactobacillus species detected) [8]. In the current study, PCR-DGGE analysis was used to monitor the effect of high temperature on major microbial populations of both wet and freeze-dried kefir culture during semi-dry and sweet low alcohol wine production. Samples of wet or freeze-dried free or immobilized culture were collected after repeated batch fermentations at 37 and $45^{\circ} \mathrm{C}$ were completed, subsequently subjected to PCR-DGGE analysis and compared to the initial kefir culture to monitor potential changes in microbial diversity (Figure 1). In most cases, no changes in kefir microbial associations were detected during high-temperature fermentations, as previously shown [15]. However, weakening of Y1 band (Kluyveromyces marxianus / Kluyveromyces lactis) signals was observed at fermentations performed at $37^{\circ} \mathrm{C}$ and very faint or no signal at fermentations performed at $45^{\circ} \mathrm{C}$ for both wet and freeze-dried cells (in comparison to the initial kefir culture) was noted. In general, the high temperatures that were applied are known to lead to yeast inactivation and to decrease of viable cells, affecting fermentation parameters, as shown above [39,40], while freeze-drying often results to a significant reduction of cell viability and poor DNA recovery $[9,41]$. Nevertheless, considering the PCR-DGGE analysis detection limit, the number of microorganisms present in the mixed culture, potential DNA template competitions, the nature of the supports involved, etc. [15], the existence of K. marxianus / K. lactis (band Y1) at $45{ }^{\circ} \mathrm{C}$ cannot be totally excluded. On the contrary, clear bands were obtained for Lactobacillus helveticus /Lactobacillus dextrinicus (B1 band), and Lactobacillus buchneri/Lactobacillus kefiri/Lactobacillus sunkii (B2/B3 band), even at $45^{\circ} \mathrm{C}$, when immobilized cells were used. This is of great importance for the wine industry, as the immobilization process seems to protect the cells enhancing the completion of malolactic fermentation at elevated temperatures $[5,32]$ in values similar or greater than those previously recorded in fermentations performed at cooler temperatures $\left(\leq 20^{\circ} \mathrm{C}\right)[6,8]$. Notably, no bands corresponding to potential spoilage microorganisms were observed.

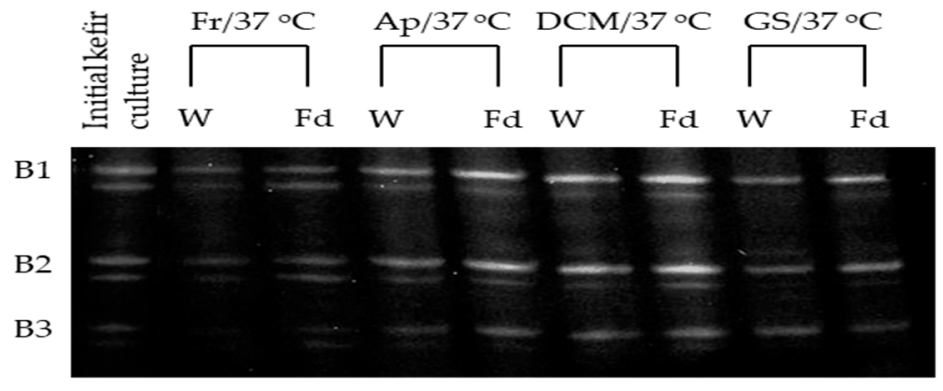

a

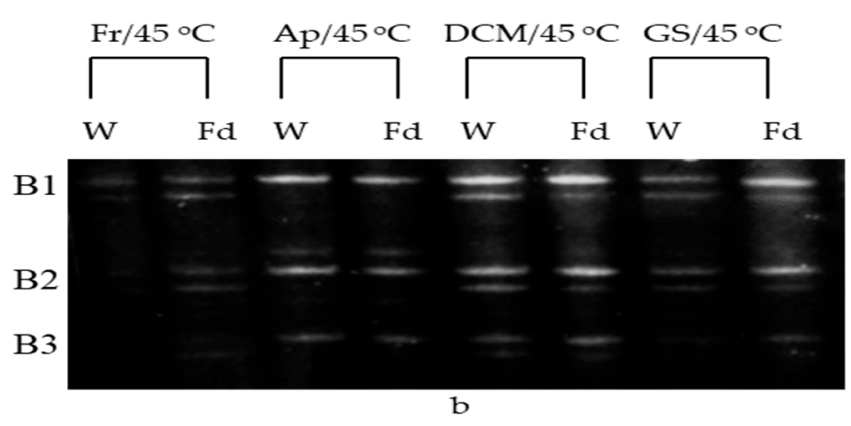

b

Figure 1. Cont. 


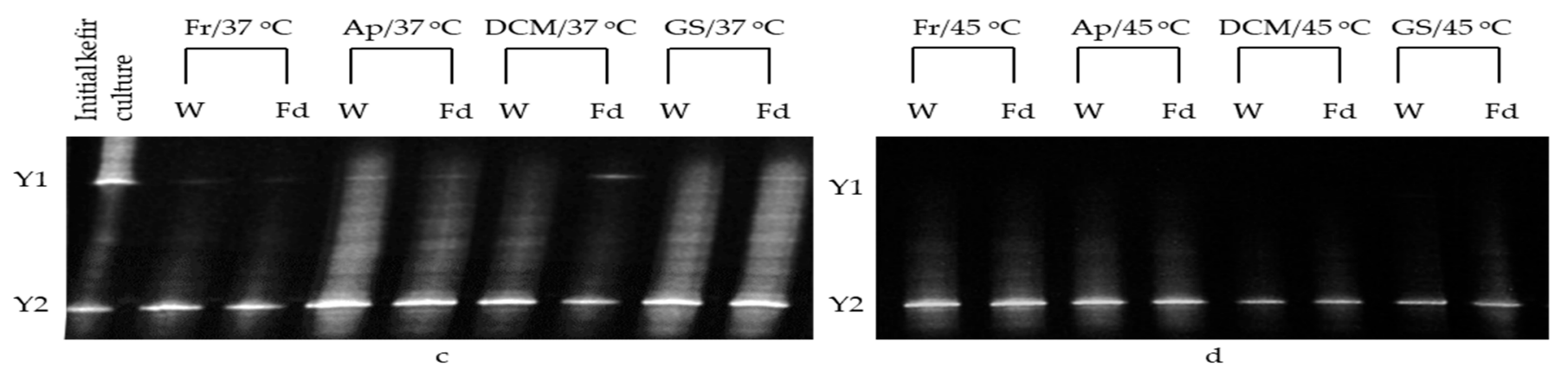

Figure 1. DGGE bacterial (a,b) and eukaryotic (c,d) fingerprint representing PCR-amplified 16S rRNA and 26S rRNA, respectively, from total community DNA derived from wet or freeze-dried free or immobilized kefir culture after semi-dry and sweet low alcohol wine-making at high temperatures $\left(37\right.$ and $45^{\circ} \mathrm{C}$ ). For each sample, two replicate profiles from two independent nucleic acid extracts were analyzed and compared to free kefir culture (prior to use in fermentations). Fr: Free kefir culture, Ap: Immobilized kefir culture on apple pieces, DCM: Immobilized kefir culture on DCM, GS: Immobilized kefir culture on grape skins. W: Wet, Fd: Freeze-dried. The fermentation temperature is shown after the sample codes. Y1 band: Kluyveromyces marxianus/Kluyveromyces lactis, Y2 band: Saccharomyces cerevisiae, B1 band: Lactobacillus helveticus/Lactobacillus dextrinicus, B2/B3 band: Lactobacillus buchneri/Lactobacillus kefiri/Lactobacillus sunkii.

\subsection{Volatiles}

\subsubsection{Major Volatiles}

Major volatile by-products detected are presented in Table 3. Ethyl acetate, acetaldehyde, and methanol concentrations were significantly $(p<0.05)$ affected by the fermentation temperature, while 1-hexanol and methanol content was significantly $(p<0.05)$ affected by the nature of the cells. Strong interactions $(p<0.05)$ were, however, noted in all cases. On the contrary, amyl and isoamyl alcohol and isobutanol content was significantly $(p<0.05)$ affected by both the state of the cells and the fermentation temperature.

Acetaldehyde, the major wine aldehyde, was detected in all products in very low levels ( $\leq 31 \mathrm{mg} / \mathrm{L})$ [19], contributing pleasantly to the product's aromatic complexity [17]. Similarly, ethyl acetate concentration, originating by yeast metabolism during alcoholic fermentation, remained in very low levels $(<50 \mathrm{mg} / \mathrm{L})$, adding pleasant notes [17]. Increased concentrations of amyl alcohol, isoamyl alcohol, isobutanol, and 1-propanol were detected in fermentations performed at $37^{\circ} \mathrm{C}$ compared to $30^{\circ} \mathrm{C}$ (control fermentations-data not shown), while fermentations with immobilized cells (wet and freeze-dried) led to higher concentrations compared to free cells, although not significantly in all cases and in values previously found during wine-making by wet and freeze-dried kefir cells [6,8]. 1-Hexanol and methanol, on the other hand, were detected in very low levels $(<50 \mathrm{mg} / \mathrm{L})$ in all samples. Higher alcohols are yeast-derived by-products produced either directly or indirectly during alcoholic fermentation and at low levels contribute to the wine's odor complexity by adding fruity characters [42,43]. In general, their formation is greatly affected by high fermentation temperatures and the presence of skins and suspended solids in the fermenting juice [17,29] and may reach $550 \mathrm{mg} / \mathrm{L}$ [43]. However, in all samples, they ranged in usual levels for wines [44].

\subsubsection{Minor Volatiles}

HS-SPME GC/MS analysis was used to evaluate the aromatic profile of low alcohol wines produced at $37^{\circ} \mathrm{C}$. Semi-quantitative results of total volatile by-products detected are presented in Table 4. 


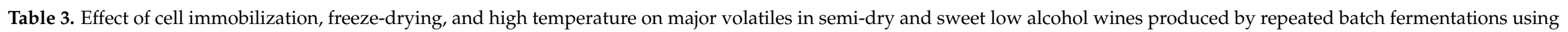
kefir culture.

\begin{tabular}{|c|c|c|c|c|c|c|c|c|c|c|c|c|c|c|c|c|c|c|}
\hline \multirow{2}{*}{\multicolumn{2}{|c|}{$\begin{array}{l}\begin{array}{c}\text { Nature of Kefir } \\
\text { Culture }\end{array} \\
\text { State of the Cells: }\end{array}$}} & \multirow[t]{2}{*}{$\mathbf{N}^{\circ}$} & \multicolumn{2}{|c|}{$\begin{array}{l}\text { Acetaldehyde } \\
(\mathrm{mg} / \mathrm{L})\end{array}$} & \multicolumn{2}{|c|}{$\begin{array}{l}\text { Ethyl Acetate } \\
\text { (mg/L) }\end{array}$} & \multicolumn{2}{|c|}{$\begin{array}{l}\text { 1-Propanol } \\
\text { (mg/L) }\end{array}$} & \multicolumn{2}{|c|}{$\begin{array}{l}\text { Isobutanol } \\
(\mathrm{mg} / \mathrm{L})\end{array}$} & \multicolumn{2}{|c|}{$\begin{array}{c}\text { 1-Hexanol } \\
(\mathrm{mg} / \mathrm{L})\end{array}$} & \multicolumn{2}{|c|}{$\begin{array}{c}\text { Amyl Alcohol } \\
(\mathrm{mg} / \mathrm{L})\end{array}$} & \multicolumn{2}{|c|}{$\begin{array}{c}\text { Isoamyl Alcohol } \\
\text { (mg/L) }\end{array}$} & \multicolumn{2}{|c|}{ Methanol (mg/L) } \\
\hline & & & W & Fd & $\mathbf{W}$ & Fd & W & Fd & W & Fd & W & Fd & $\mathbf{W}$ & Fd & $\mathbf{W}$ & Fd & $\mathbf{W}$ & Fd \\
\hline \multirow[b]{2}{*}{ Free cells } & 37 & 5 & $13-22$ & $18-31$ & $4-9$ & $3-5$ & $22-34$ & $15-24$ & $35-55$ & $22-29$ & $2-3$ & $2-3$ & $15-24$ & $10-12$ & $48-81$ & $31-39$ & $7-19$ & $4-11$ \\
\hline & 45 & 2 & $5-7$ & $4-5$ & 2 & $2-3$ & $2-5$ & $3-10$ & $3-6$ & $2-6$ & $\mathrm{Nd}$ & $0-1$ & $0-2$ & $0-2$ & $4-8$ & $1-7$ & $0-3$ & $1-4$ \\
\hline \multirow{2}{*}{$\begin{array}{l}\text { Immob. cells on } \\
\text { apple pieces }\end{array}$} & 37 & 5 & $11-17$ & $9-16$ & $5-6$ & $3-5$ & $42-53$ & $16-32$ & $44-60$ & $23-41$ & $3-5$ & $2-6$ & $20-28$ & $10-16$ & $60-82$ & $31-51$ & $13-32$ & $5-13$ \\
\hline & 45 & 2 & $12-14$ & $10-25$ & $6-7$ & $4-5$ & $16-18$ & $4-9$ & $13-20$ & $5-11$ & 3 & $0-2$ & $6-9$ & $5-8$ & $17-27$ & $14-15$ & $10-11$ & $5-13$ \\
\hline Immob. cells on & 37 & 5 & $11-19$ & $13-21$ & $4-8$ & $4-8$ & $21-43$ & $33-59$ & $24-80$ & $32-58$ & $1-4$ & $2-3$ & $12-29$ & $14-23$ & $42-100$ & $47-93$ & $4-16$ & $6-15$ \\
\hline DCM & 45 & 2 & $11-28$ & $7-11$ & $3-5$ & 3 & $5-18$ & $5-10$ & $8-25$ & $7-11$ & 2 & 2 & $3-11$ & $3-5$ & $11-38$ & $10-16$ & 18 & $4-6$ \\
\hline \multirow{2}{*}{$\begin{array}{l}\text { Immob. cells on } \\
\text { grape skins }\end{array}$} & 37 & 5 & $10-17$ & $8-23$ & $3-6$ & $3-10$ & $20-48$ & $16-55$ & $40-98$ & $16-89$ & $2-4$ & $2-7$ & $13-28$ & $7-26$ & $45-97$ & 23-104 & $6-21$ & $8-39$ \\
\hline & 45 & 2 & $8-11$ & $7-8$ & $2-3$ & $3-4$ & $3-10$ & $4-10$ & $5-15$ & $2-7$ & $1-2$ & $\mathrm{Nd}$ & $5-8$ & 2 & $12-18$ & $8-12$ & $8-13$ & $6-7$ \\
\hline \multicolumn{19}{|c|}{$F$-values } \\
\hline \multicolumn{3}{|c|}{ State of the cells } & \multicolumn{2}{|c|}{0.42} & \multicolumn{2}{|c|}{2.20} & \multicolumn{2}{|c|}{2.69} & \multicolumn{2}{|c|}{$5.89 *$} & \multicolumn{2}{|c|}{1.75} & \multicolumn{2}{|c|}{$10.93^{* *}$} & \multicolumn{2}{|c|}{$7.03 *$} & \multicolumn{2}{|c|}{$4.44 *$} \\
\hline \multirow{2}{*}{\multicolumn{3}{|c|}{$\begin{array}{l}\text { Nature of kefir culture } \\
\text { Fermentation temperature }\end{array}$}} & \multicolumn{2}{|c|}{2.18} & \multicolumn{2}{|c|}{2.06} & \multicolumn{2}{|c|}{$3.13^{*}$} & \multicolumn{2}{|c|}{1.51} & \multicolumn{2}{|c|}{$4.42 * *$} & \multicolumn{2}{|c|}{2.09} & \multicolumn{2}{|c|}{2.15} & \multicolumn{2}{|c|}{2.59} \\
\hline & & & 14 . & & & & & & 64. & & & & & & 85. & $4^{* *}$ & & \\
\hline All interact & ons & & & & & & & & & & & & & & & & & \\
\hline
\end{tabular}

$\mathrm{N}^{\circ}$ : Number of repeated fermentation batches; W: Wet cells, Fd: Freeze-dried cells; Nd: Not detected; ${ }^{*} p<0.05,{ }^{* *} p<0.01$. 
Table 4. Effect of cell immobilization and freeze-drying on minor volatile compounds (mg/L) identified in semi-dry and sweet low alcohol wines produced by kefir culture at $37^{\circ} \mathrm{C}$ using HS-SPME GC/MS analysis. Volatiles were semi-quantified using 4-methyl-2-pentanol as internal standard.

\begin{tabular}{|c|c|c|c|c|c|c|c|c|c|c|}
\hline \multirow[b]{2}{*}{ Compounds } & \multirow[b]{2}{*}{ KI } & \multirow[b]{2}{*}{ F-Values } & \multicolumn{2}{|c|}{ Free Kefir Culture } & \multicolumn{2}{|c|}{$\begin{array}{l}\text { Kefir Immob. on } \\
\text { Apple Pieces }\end{array}$} & \multicolumn{2}{|c|}{ Kefir Immob. on DCM } & \multicolumn{2}{|c|}{$\begin{array}{l}\text { Kefir Immob. On } \\
\text { Grape Skins }\end{array}$} \\
\hline & & & Wet & $\begin{array}{l}\text { Freeze- } \\
\text { Dried }\end{array}$ & Wet & $\begin{array}{l}\text { Freeze- } \\
\text { Dried }\end{array}$ & Wet & $\begin{array}{l}\text { Freeze- } \\
\text { Dried }\end{array}$ & Wet & $\begin{array}{l}\text { Freeze- } \\
\text { Dried }\end{array}$ \\
\hline \multicolumn{11}{|l|}{ Esters } \\
\hline Ethyl acetate & $<700$ & & $1.4-4.0$ & $1.1-3.1$ & $2.0-9.0$ & $1.8-8.7$ & $3.0-10.2$ & $6.5-19.8$ & $4.4-6.1$ & $3.4-22.7$ \\
\hline $\begin{array}{c}\text { Ethyl } \\
\text { propanoate }\end{array}$ & 707 & & $0.0-0.2$ & $0.0-0.3$ & $0.0-0.1$ & $0.0-0.1$ & $\mathrm{Nd}$ & $0.0-0.2$ & $0.0-0.1$ & $0.0-0.2$ \\
\hline Isobutyl acetate & 745 & & $0.0-0.1$ & $\mathrm{Nd}$ & $0.0-0.2$ & $\mathrm{Nd}$ & $0.0-0.1$ & $0.0-0.2$ & $0.1-0.3$ & $0.0-0.2$ \\
\hline Ethyl butyrate & 803 & & $0.0-0.3$ & $0.0-0.2$ & $0.2-1.0$ & $0.0-0.2$ & $0.3-0.5$ & $0.7-1.6$ & $0.4-0.6$ & $0.1-0.5$ \\
\hline $\begin{array}{l}\text { 3-methylbutyl } \\
\text { acetate (isoamyl } \\
\text { acetate) }\end{array}$ & 867 & & $0.5-2.0$ & $<0.1-1.4$ & $0.2-8.5$ & $0.2-0.4$ & $1.6-6.0$ & $4.7-18.1$ & $4.2-6.2$ & $0.7-6.2$ \\
\hline $\begin{array}{l}\text { 2-methylbutyl } \\
\text { acetate }\end{array}$ & 869 & & $0.0-0.2$ & $0.0-0.1$ & $<0.1-0.9$ & $<0.1$ & $0.0-0.2$ & $0.1-1.3$ & $0.1-0.4$ & $0.0-0.5$ \\
\hline Ethyl hexanoate & 1002 & & $0.5-1.8$ & $0.5-1.6$ & $0.6-8.9$ & $0.4-1.5$ & $1.8-6.3$ & $2.8-12.0$ & $3.4-11.7$ & $0.0-5.6$ \\
\hline $\begin{array}{c}\text { Diethyl } \\
\text { butanedioate }\end{array}$ & 1191 & & $\mathrm{Nd}$ & $0.0-0.4$ & $\mathrm{Nd}$ & $0.0-0.1$ & $\mathrm{Nd}$ & $\mathrm{Nd}$ & $0.1-1.8$ & $0.0-0.7$ \\
\hline Ethyl octanoate & 1202 & & $9.6-46.8$ & $3.7-15.3$ & $3.6-59.8$ & $3.1-7.3$ & $18.2-61.8$ & $\begin{array}{l}20.3- \\
102.3\end{array}$ & $\begin{array}{l}22.8- \\
105.2\end{array}$ & $4.3-32.2$ \\
\hline $\begin{array}{l}\text { 2-phenylethyl } \\
\text { acetate }\end{array}$ & 1263 & & $0.4-2.8$ & $0.0-0.7$ & $0.1-1.9$ & $\mathrm{Nd}$ & $1.3-2.7$ & $2.4-29.0$ & $0.9-5.2$ & $0.5-2.0$ \\
\hline $\begin{array}{c}\text { Ethyl } \\
\text { 9-decenoate }\end{array}$ & 1390 & & $0.6-17.2$ & $0.3-4.1$ & $0.0-1.5$ & $0.0-0.1$ & $2.7-14.1$ & $0.8-3.0$ & $0.6-8.5$ & $1.2-3.3$ \\
\hline Ethyl decanoate & 1398 & & $3.1-55.3$ & $1.2-14.3$ & $1.1-29.8$ & $0.9-4.2$ & $17.3-45.0$ & $9.3-47.6$ & $2.9-62.5$ & $4.1-16.8$ \\
\hline $\begin{array}{c}\text { Ethyl } \\
\text { dodecanoate }\end{array}$ & 1595 & & $0.0-0.1$ & $0.0-0.8$ & $0.1-1.5$ & $0.1-1.0$ & $0.5-2.2$ & $0.5-2.5$ & $0.1-2.3$ & $0.4-1.1$ \\
\hline $\begin{array}{c}\text { Ethyl } \\
\text { hexadecanoate }\end{array}$ & 1995 & & $\mathrm{Nd}$ & $\mathrm{Nd}$ & $\mathrm{Nd}$ & $0.0-0.5$ & $\mathrm{Nd}$ & $<0.1$ & $\mathrm{Nd}$ & $0.0-0.1$ \\
\hline \multicolumn{2}{|l|}{ Total esters } & & $\begin{array}{l}20.5- \\
127.9\end{array}$ & $11.4-33.6$ & 7.9-111.6 & $8.3-17.9$ & $\begin{array}{l}49.0- \\
119.1\end{array}$ & $\begin{array}{l}57.6- \\
234.0\end{array}$ & $\begin{array}{l}41.7- \\
194.2\end{array}$ & $28.8-64.4$ \\
\hline State of the cel & & $6.46^{*}$ & & & & & & & & \\
\hline \multicolumn{2}{|c|}{ Nature of kefir culture } & $5.90 * *$ & & & & & & & & \\
\hline \multicolumn{11}{|l|}{ Organic acids } \\
\hline Octanoic acid & 1198 & & $0.2-1.8$ & $0.0-0.3$ & $0.3-2.2$ & $\mathrm{Nd}$ & $1.0-3.4$ & $1.5-5.0$ & $0.1-1.9$ & $0.2-2.8$ \\
\hline Decanoic acid & 1381 & & $0.1-3.8$ & $0.0-0.4$ & $0.1-2.2$ & $\mathrm{Nd}$ & $1.0-5.0$ & $0.2-2.8$ & $0.1-2.3$ & $0.0-5.1$ \\
\hline $\begin{array}{l}\text { Total organic } \\
\text { acids }\end{array}$ & & & $0.3-5.1$ & $0.0-0.7$ & $0.4-4.4$ & Nd & $2.0-7.0$ & $2.3-7.4$ & $0.6-4.2$ & $0.3-6.2$ \\
\hline \multicolumn{2}{|c|}{ State of the cells } & 2.00 & & & & & & & & \\
\hline \multicolumn{2}{|c|}{ Nature of kefir culture } & $3.50 *$ & & & & & & & & \\
\hline \multicolumn{11}{|l|}{$\begin{array}{l}\text { Interaction } \\
\text { Alcohols }\end{array}$} \\
\hline $\begin{array}{l}\text { 2-methyl-1- } \\
\text { propanol } \\
\text { (isobutanol) }\end{array}$ & $<700$ & & $0.5-1.3$ & $0.4-1.9$ & $0.5-2.1$ & $0.8-2.3$ & $1.0-3.3$ & $1.1-3.0$ & $1.5-2.9$ & $0.5-4.3$ \\
\hline $\begin{array}{l}\text { 3-methyl-1- } \\
\text { butanol } \\
\text { (isoamyl } \\
\text { alcohol) }\end{array}$ & 721 & & 7.7-18.4 & $11.7-29.9$ & 9.9-31.8 & $14.2-23.6$ & $13.5-32.1$ & $24.2-58.5$ & $17.7-32.3$ & $12.7-48.4$ \\
\hline $\begin{array}{c}\text { 2-methyl-1- } \\
\text { butanol (amyl } \\
\text { alcohol) }\end{array}$ & 722 & & $3.5-8.6$ & $4.4-13.3$ & $3.3-14.5$ & $5.4-9.0$ & $5.4-12.2$ & $6.7-17.4$ & 5.3-13.6 & 4.9-18.2 \\
\hline 2,3-butanediol & 756 & & $0.0-0.8$ & $\mathrm{Nd}$ & $0.0-0.2$ & $\mathrm{Nd}$ & $\mathrm{Nd}$ & $\mathrm{Nd}$ & $\mathrm{Nd}$ & $\mathrm{Nd}$ \\
\hline $\begin{array}{c}2- \\
\text { phenylethanol } \\
\text { 2,4-bis(1,1- }\end{array}$ & 1133 & & $1.6-13.2$ & $1.1-5.9$ & $2.0-7.9$ & $0.7-3.8$ & $4.8-10.4$ & $2.1-4.4$ & $2.6-5.7$ & $0.1-7.7$ \\
\hline $\begin{array}{l}\text { dimethylethyl)- } \\
\text { phenol }\end{array}$ & 1516 & & $\mathrm{Nd}$ & $1.1-7.9$ & $\mathrm{Nd}$ & $1.3-3.1$ & $\mathrm{Nd}$ & $2.2-12.4$ & $\mathrm{Nd}$ & $0.7-3.3$ \\
\hline $\begin{array}{c}\text { 3,7,11-trimethyl- } \\
\text { 1,6,10- } \\
\text { dodecatrien-3- } \\
\text { ol } \\
\text { (nerolidol) }\end{array}$ & 1565 & & $\mathrm{Nd}$ & $0.0-0.4$ & $\mathrm{Nd}$ & $0.0-0.1$ & $\mathrm{Nd}$ & $0.0-0.2$ & $\mathrm{Nd}$ & $0.0-0.3$ \\
\hline
\end{tabular}


Table 4. Cont.

\begin{tabular}{|c|c|c|c|c|c|c|c|c|c|c|}
\hline \multirow[b]{2}{*}{ Compounds } & \multirow[b]{2}{*}{ KI } & \multirow[b]{2}{*}{$F$-Values } & \multicolumn{2}{|c|}{ Free Kefir Culture } & \multicolumn{2}{|c|}{$\begin{array}{l}\text { Kefir Immob. on } \\
\text { Apple Pieces }\end{array}$} & \multicolumn{2}{|c|}{ Kefir Immob. on DCM } & \multicolumn{2}{|c|}{$\begin{array}{l}\text { Kefir Immob. On } \\
\text { Grape Skins }\end{array}$} \\
\hline & & & Wet & $\begin{array}{l}\text { Freeze- } \\
\text { Dried }\end{array}$ & Wet & $\begin{array}{l}\text { Freeze- } \\
\text { Dried }\end{array}$ & Wet & $\begin{array}{l}\text { Freeze- } \\
\text { Dried }\end{array}$ & Wet & $\begin{array}{l}\text { Freeze- } \\
\text { Dried }\end{array}$ \\
\hline \multicolumn{2}{|l|}{ Total alcohols } & & $13.5-40.7$ & $23.4-49.9$ & $15.8-53.5$ & $27.3-36.4$ & $26.5-54.7$ & $38.3-94.9$ & $29.4-53.7$ & $19.6-81.9$ \\
\hline \multirow{2}{*}{\multicolumn{2}{|c|}{$\begin{array}{l}\text { State of the cells } \\
\text { Nature of kefir culture }\end{array}$}} & 3.74 & & & & & & & & \\
\hline & & 1.72 & & & & & & & & \\
\hline \multicolumn{2}{|c|}{ Interaction } & 0.52 & & & & & & & & \\
\hline \multicolumn{11}{|l|}{$\begin{array}{l}\text { Miscellaneous } \\
\text { compounds }\end{array}$} \\
\hline $\begin{array}{l}\text { 2-fluoro-1- } \\
\text { propene }\end{array}$ & \multicolumn{2}{|l|}{$<700$} & $0.3-1.5$ & $0.0-1.3$ & $0.3-2.7$ & $0.1-1.1$ & $0.2-2.5$ & $0.6-3.9$ & $0.5-1.4$ & $0.3-3.0$ \\
\hline $\begin{array}{l}\text { 1,1-diethoxy- } \\
\text { ethane } \\
\text { (acetal) }\end{array}$ & \multicolumn{2}{|l|}{716} & $0.4-1.4$ & $0.0-2.4$ & $0.1-0.8$ & $0.1-0.8$ & $0.2-1.3$ & $0.4-1.1$ & $0.1-0.9$ & $0.1-1.4$ \\
\hline $\begin{array}{l}\text { 1,3,5-trimethyl- } \\
\text { benzene } \\
\text { (mesitylene) }\end{array}$ & \multicolumn{2}{|l|}{956} & $\mathrm{Nd}$ & $0.0-0.3$ & $\mathrm{Nd}$ & $0.1-0.3$ & $\mathrm{Nd}$ & $0.0-0.3$ & $\mathrm{Nd}$ & $0.0-0.4$ \\
\hline $\begin{array}{c}\text { 1,3-bis(1,1- } \\
\text { dimethylethyl)- }\end{array}$ & & & & & & & & & & \\
\hline $\begin{array}{c}\text { benzene } \\
\text { (m-di-tert- } \\
\text { butylbenzene) }\end{array}$ & \multicolumn{2}{|l|}{1258} & $0.1-0.8$ & $1.4-5.6$ & $0.1-0.8$ & $0.4-2.1$ & $0.2-0.5$ & $2.2-8.2$ & $0.2-0.8$ & $0.5-3.6$ \\
\hline $\begin{array}{l}\text { Tetradecane } \\
\text { Total }\end{array}$ & \multicolumn{2}{|l|}{1399} & $\mathrm{Nd}$ & $0.0-0.6$ & $\mathrm{Nd}$ & $0.0-0.2$ & $\mathrm{Nd}$ & $0.0-0.2$ & $\mathrm{Nd}$ & $0.0-0.3$ \\
\hline \multicolumn{3}{|l|}{$\begin{array}{l}\text { miscellaneous } \\
\text { compounds }\end{array}$} & $1.0-2.7$ & $1.7-7.6$ & $0.8-3.6$ & $1.6-3.8$ & $1.2-4.0$ & $3.8-13.0$ & $1.1-2.6$ & $1.9-5.2$ \\
\hline State of the ce & & $10.76^{* *}$ & & & & & & & & \\
\hline \multicolumn{2}{|c|}{ Nature of kefir culture } & 1.65 & & & & & & & & \\
\hline \multicolumn{2}{|c|}{ Interaction } & 1.51 & & & & & & & & \\
\hline \multicolumn{2}{|c|}{ Total volatiles } & & $\begin{array}{l}35.3- \\
176.3\end{array}$ & $42.8-80.0$ & $\begin{array}{l}24.9- \\
169.5\end{array}$ & $39.9-57.4$ & $\begin{array}{l}91.6- \\
169.9\end{array}$ & $\begin{array}{l}111.8- \\
344.9\end{array}$ & $\begin{array}{l}74.5- \\
241.8\end{array}$ & $\begin{array}{l}51.1- \\
134.9\end{array}$ \\
\hline \multirow{2}{*}{\multicolumn{2}{|c|}{$\begin{array}{l}\text { State of the cells } \\
\text { Nature of kefir culture }\end{array}$}} & 1.53 & & & & & & & & \\
\hline & & $4.86^{* *}$ & & & & & & & & \\
\hline \multicolumn{2}{|c|}{$\begin{array}{l}\text { Nature of kefir culture } \\
\text { Interaction }\end{array}$} & 1.51 & & & & & & & & \\
\hline
\end{tabular}

KI: Kovats retention index; Nd: Not detected; ${ }^{*} p<0.05,{ }^{* *} p<0.01$.

Totally, 28 compounds (including esters, organic acids and alcohols) were identified. The nature and the state of kefir culture affected significantly $(p<0.05)$ the concentration of esters. Acid and total volatile content was significantly $(p<0.05)$ affected by the nature of kefir culture, while strong interactions $(p<0.05)$ between the two factors were observed. On the contrary, no significant differences were observed in alcohols, while miscellaneous compounds were significantly $(p<0.05)$ affected only by the state of kefir culture. In general, fluctuations observed in volatile constitution of semi-dry and sweet low alcohol wines fermented with freeze-dried immobilized cells are fully justified (when compared to low alcohol wines fermented with wet immobilized cells) and may occur as a result of the freeze-drying process [45].

An increase in esters concentration was observed in fermentations with immobilized cells on grape skins and DCM compared to apple pieces and free cells, although not significant in all cases. The synthesis of higher-molecular weight esters (ethyl octanoate, ethyl decanoate, 2-phenylethyl acetate) is favored on higher temperatures, while their production was probably also promoted by cell immobilization $[17,46]$. Acetate esters of higher alcohols are fermentation by-products that have been widely associated with wine fruitiness [47]. Despite the high fermentation temperature, esters responsible for banana-like scents (isoamyl acetate and 3-methylbutyl acetate), apple-peel attributes (ethyl butyrate), peer flavors (2-methylbutyl acetate), pineapple notes (ethyl hexanoate), floral, fruity, musty and other pleasant notes (ethyl octanoate, ethyl decanoate and ethyl-9-decenoate), as well as dried fruit, smokey, earthy, and toasty aromas (ethyl dodecanoate) $[17,20,44,48]$ were detected in all samples. Likewise, esters known for their fresh and fruity character (ethyl propanoate, isobutyl acetate, 2 -phenylethyl acetate) $[17,44]$ were found in most samples 
and are also present in wines [6,8,49]. Ethyl hexadecanoate, on the other hand, providing candy, herbal, and spicy scents [48], was detected in very low concentrations only in fermentations with freeze-dried immobilized cells.

Regarding fatty acids, octanoic acid and $n$-decanoic acid were identified in all samples, except in wines produced by freeze-dried immobilized cells on apple pieces. Both acids are known for their low odor threshold limit and may have an impact on wine flavor [48]. An increase in fatty acids content was observed in wines fermented by immobilized cells on DCM [8], although not significant in all cases, suggesting improvement of product quality [44].

Regarding alcohols, 2,3-butanediol (probably derived from yeast-induced reduction of ML fermentation by-products like diacetyl and acetoin), known for its bittersweet taste, is probably of low sensory importance for wine [17,47]. However, it was detected only in products produced by wet free and immobilized cells on apple pieces. 2-Phenyl-ethanol, on the other hand, with a characteristic rose aroma, was found in all wines, while nerolidol with mostly hay flavors was only identified (in low quantities) in wines produced with freeze-dried cells $[8,16]$.

As for miscellaneous compounds is concerned, 1,1-diethoxy-ethane, recognized for its fruity-green and refreshing scent, is probably the only acetal that may contribute to the wine bouquet $[17,44]$. Hydrocarbons, such as tetradecane (it was identified only in wines produced with freeze-dried cells) are considered mostly insignificant to wine aroma [17].

HS-SPME GC/MS results were also subjected to PCA, which showed that the state of the cells rather than the nature of kefir culture affected significantly volatile composition (see Figure S1 on Supplementary Materials).

\subsection{Preliminary Sensory Evaluation}

Low alcohol wines produced at high temperatures were assessed for their sensory characteristics (Table 5). The aroma and the taste of all products were significantly $(p<0.05)$ affected by the fermentation temperature and the nature of kefir culture, while strong interactions $(p<0.05)$ were noted between the factors. In contrast, overall quality was affected significantly $(p<0.05)$ by the three factors (state and nature of kefir culture and fermentation temperature), but no interactions were observed.

Table 5. Sensory evaluation of semi-dry and sweet low alcohol wines produced by wet and freeze-dried kefir culture at high temperatures $\left(37\right.$ and $\left.45^{\circ} \mathrm{C}\right)$.

\begin{tabular}{cccccccc}
\hline $\begin{array}{c}\text { Fermentation } \\
\text { Temperature } \\
\left({ }^{\circ} \mathbf{C}\right)\end{array}$ & $\begin{array}{c}\text { Low Alcohol } \\
\text { Wine Sample }\end{array}$ & \multicolumn{6}{c}{ Quality Attribute } \\
\cline { 3 - 8 } State of the Cells: & \multicolumn{2}{c}{ Aroma } & & \multicolumn{2}{c}{ Taste } & \multicolumn{2}{c}{ Overall Quality } \\
\hline & Fr & $3.3 \pm 0.4$ & $3.3 \pm 0.4$ & $3.2 \pm 0.6$ & $3.3 \pm 0.4$ & $3.1 \pm 0.6$ & $3.0 \pm 0.5$ \\
37 & Ap & $2.5 \pm 0.4$ & $2.6 \pm 0.4$ & $3.4 \pm 0.7$ & $3.6 \pm 0.3$ & $3.2 \pm 0.6$ & $3.1 \pm 0.6$ \\
& DCM & $3.0 \pm 0.3$ & $3.3 \pm 0.5$ & $3.6 \pm 0.5$ & $3.6 \pm 0.5$ & $3.7 \pm 0.5$ & $3.6 \pm 0.5$ \\
& GS & $2.7 \pm 0.6$ & $2.5 \pm 0.3$ & $3.3 \pm 0.6$ & $3.2 \pm 0.5$ & $3.5 \pm 0.5$ & $3.2 \pm 0.4$ \\
\hline & Fr & $2.4 \pm 0.3$ & $2.0 \pm 0.5$ & $2.5 \pm 0.6$ & $2.4 \pm 0.5$ & $2.5 \pm 0.5$ & $2.4 \pm 0.5$ \\
45 & Ap & $2.2 \pm 0.5$ & $2.4 \pm 0.5$ & $2.9 \pm 0.6$ & $2.9 \pm 0.7$ & $2.7 \pm 0.6$ & $2.5 \pm 0.5$ \\
& DCM & $2.4 \pm 0.6$ & $2.7 \pm 0.7$ & $3.8 \pm 0.4$ & $3.4 \pm 0.7$ & $3.1 \pm 0.6$ & $3.0 \pm 0.8$ \\
& GS & $2.2 \pm 0.6$ & $2.3 \pm 0.5$ & $3.4 \pm 0.7$ & $2.8 \pm 0.5$ & $3.1 \pm 0.5$ & $2.7 \pm 0.5$ \\
\hline
\end{tabular}

Fr: semi-dry and sweet low alcohol wines fermented by free kefir culture, Ap: semi-dry and sweet low alcohol wines fermented by immobilized kefir culture on apple pieces, DCM: semi-dry and sweet low alcohol wines fermented by immobilized kefir culture on DCM, GS: semi-dry and sweet low alcohol wines fermented by immobilized kefir culture on grape skins; W: Wet cells, Fd: Freeze-dried cells; 0: unacceptable, 5: wonderful.

Although no post-fermentation treatments were followed, all new products were distinguished for their high clarity and were approved by the sensory panel. Regarding taste, all wines produced at $37{ }^{\circ} \mathrm{C}$ were characterized as sour or sweet/sour and were mostly light-bodied. At $45^{\circ} \mathrm{C}$, owing to the increased residual sugars, wine products fermented with immobilized cells had a sweet taste and a pleasant smooth aftertaste with a 
medium body. On the contrary, wine products fermented with free cells were characterized as "too sweet", in some cases, due to the excessive residual sugars and scored low values. Concerning the aroma attribute, wines produced at $37^{\circ} \mathrm{C}$ were mainly characterized by fruity and wine-like scents and piquant and spirituous notes were identified in some samples fermented with immobilized cells on grape skins and DCM, respectively [8]. Remarkably, wines fermented by immobilized cells on DCM scored the highest overall quality ranking, although not significantly in all cases.

\subsection{Technological Considerations}

The strategy adopted involved the immobilization of kefir culture, a mixed culture previously tested in simultaneous alcoholic and ML wine fermentation, on natural foodgrade supports with minimum cost $[6,8]$. Specifically, DCM is an abundant material, while grape skins are wine industry by-products of negligible cost. Their use consists a sustainable alternative to their uncontrolled disposal, which is associated with major environmental concerns [34]. The use of apples pieces, on the other hand, in addition to their low cost considering the high amounts deliberately destroyed for economic reasons, contributes favorably to the fruity character of the final product. Immobilized cells can be easily removed after fermentation completion and reused to the next fermentation run with similar or even enhanced fermentation activity. Industrialization of the process may require an integrated cost effective continuous fermentation system consisting of a multi-stage fixed bed tower (MFBT) bioreactor [50], with the ability of cell regeneration. Nevertheless, the technology proposed could be easily adopted by the traditional wine-making industries, as it is simple and there is no need for extensive training of the human resources.

Wine fermentation is nowadays performed at fixed temperature range both for white and red wine-making. However, temperature control, mixing, and agitation costs may add up to $26 \%$ of industrial fermentation costs [51] or even greater in regions with tropical climate or hot summer periods. Although sterilization and other pre-treatment process steps are known to be cost and energy demanding and their elimination may save up to $30-40 \%$ of the total energy needed [52,53], in our study, no agitation or aerization was needed during the repeated batch fermentations, decreasing further the operational costs. The high fermentation temperatures applied (mostly in red wine-making) are known to enhance extraction of color, phenolics, and tannins from fruit skins during winemaking [54], a characteristic that could be used to enhance aroma and color in the wine industry [55]. Importantly, the selected food-grade immobilization supports (apple pieces, DCM, grape skins) may act favorably for plain, "neutral", cultivars like Savatiano and Roditis [56] by adding freshness and fruitiness to the final product [10]. In addition, a high initial inoculum of kefir culture was used in wine fermentations and thus prevalence of a wild-type yeast or bacteria culture is highly unlikely even in non-sterile must.

The development of new low alcohol wine products is also a necessity driven by the consumers' social, economic interests and health concerns [1]. The common practice requires physicochemical methods applied (membrane systems, vacuum or osmotic distillation, spinning cone technology and supercritical carbon dioxide ex-traction) that are known to affect negatively the wine quality and characteristics, thus compromising wine flavor and consumer acceptance, while increasing unnecessarily the cost of production [1]. In our study, wine fermentations with immobilized kefir culture at $37^{\circ} \mathrm{C}$ led to semi-dry low alcohol wines, as residual sugars in the final products ranged between $1.5 \mathrm{~g} / \mathrm{L}$ and $20 \mathrm{~g} / \mathrm{L}$ (by mean values) $[17,43]$. Fermentations at $45^{\circ} \mathrm{C}$ were also tested and although they resulted in high residual sugars $(>36 \mathrm{~g} / \mathrm{L}$ ), they could be exploited for novel low alcohol wine products with a sweet (liquoreux) character [43]. Afterall, modern approaches recommend low alcohol wines to be blended with grape juice (after post-fermentative alcohol extraction), in order to enhance the aromatic intensity and improve the mouthfeel [57], a procedure however time-consuming and cost-demanding.

Hence, adoption of the proposed technology (especially in regions with tropical climate or hot summer periods) could eliminate the necessity of cooling systems, leading 
to drastic reduction of operational costs, while producing high quality novel low alcohol products. Nevertheless, more research is still required in important issues like maintenance of cell viability and fermentation efficiency during storage of freeze-dried cells among the enological periods, in order to meet the modern commercial needs and allow industrialization of the proposed technology.

\section{Conclusions}

Both wet and freeze-dried immobilized kefir cells on natural supports proved to be suitable for simultaneous alcoholic and ML low alcohol wine production at high temperatures $\left(>30^{\circ} \mathrm{C}\right)$. Repeated batch fermentations using wet or freeze-dried free or immobilized kefir culture lasted for up to 3 months, suggesting a high operational stability of the systems, while ethanol concentration and daily ethanol productivity values ranged in levels that could be adopted by the wine industry. In spite of the high residual sugars observed at $45^{\circ} \mathrm{C}$, fermentations with immobilized kefir culture could also be exploited for novel low alcohol wine product development with a sweet (liquoreux) character.

Supplementary Materials: The following are available online at https:/ /www.mdpi.com/2311-563 $7 / 7 / 2 / 45 /$ s1.

Author Contributions: Conceptualization, A.N. and Y.K.; Data curation, Investigation, Methodology, A.N.; Project administration, Supervision, Y.K; Writing—original draft, A.N.; Writing—review \& editing, A.N. and Y.K. All authors have read and agreed to the published version of the manuscript.

Funding: This research was funded by the "Infrastructure of Microbiome Applications in Food Systems-FOODBIOMES".

Institutional Review Board Statement: Not applicable.

Informed Consent Statement: Not applicable.

Acknowledgments: We acknowledge support of this work by the project "Infrastructure of Microbiome Applications in Food Systems-FOODBIOMES" (MIS 5047291), which is implemented under the Action "Regional Excellence in R\&D Infrastructures", funded by the Operational Programme "Competitiveness, Entrepreneurship and Innovation" (NSRF 2014-2020) and co-financed by Greece and the European Union (European Regional Development Fund).

Conflicts of Interest: The authors declare no conflict of interest.

\section{References}

1. Goold, H.D.; Kroukamp, H.; Williams, T.C.; Paulsen, I.T.; Varela, C.; Pretorius, I.S. Yeast's balancing act between ethanol and glycerol production in low-alcohol wines. Microb. Biotechnol. 2017, 10, 264-278. [CrossRef]

2. Pickering, G.J. Low and Reduced-alcohol Wine: A Review. J. Wine Res. 2000, 11, 129-144. [CrossRef]

3. Saliba, A.J.; Ovington, L.A.; Moran, C.C. Consumer demand for low-alcohol wine in an Australian sample. Int. J. Wine Res. 2013, 5, 1-8. [CrossRef]

4. Varela, C.; Dry, P.R.; Kutyna, D.R.; Francis, I.L.; Henschke, P.A.; Curtin, C.D.; Chambers, P.J. Strategies for reducing alcohol concentration in wine. Aust. J. Grape Wine Res. 2015, 21, 670-679. [CrossRef]

5. Agouridis, N.; Bekatorou, A.; Nigam, P.; Kanellaki, M. Malolactic fermentation in wine with Lactobacillus casei cells immobilized on Delignified cellulosic material. J. Agric Food Chem. 2005, 53, 2546-2551. [CrossRef]

6. Nikolaou, A.; Tsakiris, A.; Kanellaki, M.; Bezirtzoglou, E.; Akrida-Demertzi, K.; Kourkoutas, Y. Wine production using free and immobilized kefir culture on natural supports. Food Chem. 2019, 272, 39-48. [CrossRef] [PubMed]

7. Kourkoutas, Y.; Manojlović, V.; Nedović, V.A. Immobilization of Microbial Cells for Alcoholic and Malolactic Fermentation of Wine and Cider. In Encapsulation Technologies for Active Food Ingredients and Food Processing; Zuidam, N.J., Nedovic, V., Eds.; Springer: New York, NY, USA, 2010; pp. 327-343.

8. Nikolaou, A.; Sgouros, G.; Mitropoulou, G.; Santarmaki, V.; Kourkoutas, Y. Freeze-dried Immobilized Kefir Culture in Low Alcohol Wine-Making. Foods 2020, 9, 115. [CrossRef]

9. Dimitrellou, D.; Kandylis, P.; Kourkoutas, Y. Effect of cooling rate, freeze-drying, and storage on survival of free and immobilized Lactobacillus casei ATCC 393. LWT Food Sci. Technol. 2016, 69, 468-473. [CrossRef]

10. Kourkoutas, Y.; Bekatorou, A.; Banat, I.M.; Marchant, R.; Koutinas, A.A. Immobilization technologies and support materials suitable in alcohol beverages production: A review. Food Microbiol. 2004, 21, 377-397. [CrossRef] 
11. Bekatorou, A.; Plessas, S.; Mallouchos, A. Cell Immobilization Technologies for Applications in Alcoholic Beverages. In Handbook of Encapsulation and Controlled Release; Mishra, M., Ed.; CRC Press: Boca Raton, FL, USA, 2015; pp. $933-955$.

12. Plessas, S.; Nouska, C.; Mantzourani, I.; Kourkoutas, Y.; Alexopoulos, A.; Bezirtzoglou, E. Microbiological Exploration of Different Types of Kefir Grains. Fermentation 2017, 3, 1. [CrossRef]

13. Garofalo, C.; Osimani, A.; Milanović, V.; Aquilanti, L.; De Filippis, F.; Stellato, G.; Di Mauro, S.; Turchetti, B.; Buzzini, P.; Ercolini, D.; et al. Bacteria and yeast microbiota in milk kefir grains from different Italian regions. Food Microbiol. 2015, 49, 123-133. [CrossRef] [PubMed]

14. Prado, M.R.; Blandón, L.M.; Vandenberghe, L.P.; Rodrigues, C.; Castro, G.R.; Thomaz-Soccol, V.; Soccol, C.R. Milk kefir: Composition, microbial cultures, biological activities, and related products. Front. Microbiol. 2015, 6, 1177. [CrossRef] [PubMed]

15. Nikolaou, A.; Galanis, A.; Kanellaki, M.; Tassou, C.; Akrida-Demertzi, K.; Kourkoutas, Y. Assessment of free and immobilized kefir culture in simultaneous alcoholic and malolactic cider fermentations. LWT-Food Sci. Technol. 2017, 76, 67-78. [CrossRef]

16. Nikolaou, A.; Nelios, G.; Kanellaki, M.; Kourkoutas, Y. Freeze-dried immobilized kefir culture in cider-making. J. Sci. Food Agric. 2020, 100, 3319-3327. [CrossRef]

17. Jackson, R.S. Wine Science: Principles and Applications, 4th ed.; Academic Press Inc.: San Diego, CA, USA, 2014.

18. Molina, A.; Swiegers, J.; Varela, C.; Pretorus, I.; Agosin, E. Influence of wine fermentation temperature on the synthesis of yeast-derived volatile aroma compounds. Appl. Microbiol. Biotechnol. 2007, 77, 675-687. [CrossRef] [PubMed]

19. Kopsahelis, N.; Bosnea, L.; Kanellaki, M.; Koutinas, A.A. Volatiles Formation from Grape Must Fermentation Using a Cryophilic and Thermotolerant Yeast. Appl. Biochem. Biotechnol. 2012, 167, 1183-1198. [CrossRef] [PubMed]

20. Rajoka, M.I.; Ferhan, M.; Khalid, A.M. Kinetics and thermodynamics of ethanol production by a thermotolerant mutant of Saccharomyces cerevisiae in a microprocessor-controlled bioreactor. Lett. Appl. Microbiol. 2005, 40, 316-321. [CrossRef]

21. Sidira, M.; Galanis, A.; Nikolaou, A.; Kanellaki, M.; Kourkoutas, Y. Evaluation of Lactobacillus casei ATCC 393 protective effect against spoilage of probiotic dry-fermented sausages. Food Control 2014, 42, 315-320. [CrossRef]

22. Sipsas, V.; Kolokythas, G.; Kourkoutas, Y.; Plessas, S.; Nedovic, V.A.; Kanellaki, M. Comparative study of batch and continuous multi-stage fixed-bed tower (MFBT) bioreactor during wine-making using freeze-dried immobilized cells. J. Food Eng. 2009, 90, 495-503. [CrossRef]

23. Bosnea, L.A.; Kourkoutas, Y.; Albantaki, N.; Tzia, C.; Koutinas, A.A.; Kanellaki, M. Functionality of freeze-dried L. casei cells immobilized on wheat grains. LWT Food Sci. Technol. 2009, 42, 1696-1702. [CrossRef]

24. Iconomopoulou, M.; Kanellaki, M.; Psarianos, K.; Koutinas, A.A. Delignified cellulosic material supported biocatalyst as freeze-dried product in alcoholic fermentation. J. Agric. Food Chem. 2000, 48, 958-961. [CrossRef]

25. Guyot, S.; Ferret, E.; Gervais, P. Yeast survival during thermal and osmotic shocks is related to membrane phase change. J. Agric. Food Chem. 2006, 54, 8450-8455. [CrossRef] [PubMed]

26. Kourkoutas, Y.; McErlean, C.; Kanellaki, M.; Hack, C.J.; Marchant, R.; Banat, I.M.; Koutinas, A.A. High-temperature wine making using the thermotolerant yeast strain Kluyveromyces cerevisiae IMB3. Appl. Biochem. Biotechnol. 2004, 112, 25-35. [CrossRef]

27. Mitropoulou, G.; Nikolaou, A.; Santarmaki, V.; Sgouros, G.; Kourkoutas, Y. Citrus medica and Cinnamomum zeylanicum Essential Oils as Potential Biopreservatives against Spoilage in Low Alcohol Wine Products. Foods 2020, 9, 577. [CrossRef] [PubMed]

28. Mallios, P.; Kourkoutas, Y.; Iconomopoulou, M.; Koutinas, A.A.; Psarianos, C.; Marchant, R.; Banat, I.M. Low-temperature wine-making using yeast immobilized on pear pieces. J. Sci. Food Agric. 2004, 84, 1615-1623. [CrossRef]

29. Servetas, I.; Berbegal, C.; Camacho, N.; Bekatorou, A.; Ferrer, S.; Nigam, P.; Drouza, C.; Koutinas, A.A. Saccharomyces cerevisiae and Oenococcus oeni immobilized in different layers of a cellulose/starch gel composite for simultaneous alcoholic and malolactic wine fermentations. Process Biochem. 2013, 48, 1279-1284. [CrossRef]

30. Nurgel, C.; Pickering, G.J.; Inglis, D.L. Sensory and chemical characteristics of Canadian ice wines. J. Sci. Food Agric. 2004, 84, 1675-1684. [CrossRef]

31. Remize, F.; Sablayrolles, J.M.; Dequin, S. Re-assessment of the influence of yeast strain and environmental factors on glycerol production in wine. J. Appl. Microbiol. 2000, 88, 371-378. [CrossRef] [PubMed]

32. Vila-Crespo, J.; Rodriguez-Nogales, J.M.; Fernandéz-Fernandéz, E.; Hernanz-Moral, M.C. Strategies for the enhancement of malolactic fermentation in the new climate conditions. In Current Research, Technology and Education Topics in Applied Microbiology and Microbial Biotechnology; Méndez-Vilas, A., Ed.; Formatex Research Center: Badajoz, Spain, 2010; pp. $920-929$.

33. Kosseva, M.R.; Beschkov, V.; Kennedy, J.F.; Lloyd, L.L. Malolactic fermentation in Chardonnay wine by immobilized Lactobacillus casei cells. Process Biochem. 1998, 33, 793-797. [CrossRef]

34. Genisheva, Z.; Mussatto, S.I.; Oliveira, J.M.; Teixeira, J.A. Malolactic fermentation of wines with immobilised lactic acid bacteriaInfluence of concentration, type of support material and storage conditions. Food Chem. 2013, 138, 1510-1514. [CrossRef]

35. Agouridis, N.; Kopsahelis, N.; Plessas, S.; Koutinas, A.A.; Kanellaki, M. Oenococcus oeni cells immobilized on delignified cellulosic material for malolactic fermentation of wine. Bioresour. Technol. 2008, 99, 9017-9020. [CrossRef] [PubMed]

36. Nedović, V.A.; Durieux, A.; Van Nedervelde, L.; Rosseels, P.; Vandegans, J.; Plaisant, A.M.; Simon, J.P. Continuous cider fermentation with coimmobilized yeast and Leuconostoc oenos cells. Enzyme Microb. Technol. 2000, 26, 834-839. [CrossRef]

37. Kandylis, P.; Goula, A.; Koutinas, A.A. Corn starch gel for yeast cell entrapment. A view for catalysis of wine fermentation. J. Agric. Food Chem. 2008, 56, 12037-12045. [CrossRef]

38. Moreno, J.; Peinado, R. Composition of Grape Must. In Enological Chemistry; Academic Press: London, UK, 2012 ; pp. 13-22. 
39. Torija, M.J.; Rosès, N.; Poblet, M.; Guillamon, J.M.; Mas, A. Effects of fermentation temperature on the strain population of Saccharomyces cerevisiae. Int. J. Food Microbiol. 2003, 80, 47-53. [CrossRef]

40. Peng, B.; Li, F.; Cui, L.; Guo, Y. Effects of Fermentation Temperature on Key Aroma Compounds and Sensory Properties of Apple Wine. J. Food Sci. 2015, 80, 2937-2943. [CrossRef]

41. Michaelsen, A.; Pinzari, F.; Barbabietola, N.; Piñar, G. Monitoring the effects of different conservation treatments on paper-infecting fungi. Int. Biodeter. Biodegr. 2013, 84, 333-341. [CrossRef]

42. Bartowsky, E.J.; Pretorius, I.S. Microbial formation and modification of flavor and off-flavor compounds in wine. In Biology of Microorganisms on Grapes, in Must and in Wine; König, H., Unden, G., Fröhlich, J., Eds.; Springer: Heidelberg/Berlin, Germany, 2009.

43. Ribereau-Gayon, P.; Glories, Y.; Maujean, A.; Dubourdieu, D. Hanbook of Enology; Wiley: Chichester, UK, 2006.

44. Etiévant, X.P. Wine. In Volatile Compounds in Foods and Beverages; Maarse, H., Ed.; Marcel Dekker: New York, NY, USA, 1991; pp. 483-533.

45. De Torres, C.; Schumacher, R.; Alanon, M.E.; Perez-Coello, M.S.; Díaz-Maroto, M.C. Freeze-dried grape skins by-products to enhance the quality of white wines from neutral grape varieties. Food Res. Int. 2015, 69, 97-105. [CrossRef]

46. Nedović, V.; Gibson, B.; Mantzouridou, T.F.; Bugarski, B.; Djordjevic, V.; Kaluševic, A.; Paraskevopoulou, A.; Sandell, M.; Šmogrovičová, D.; Yilmaztekin, M. Aroma formation by immobilized yeast cells in fermentation processes. Yeast 2015, 32, 173-216. [CrossRef] [PubMed]

47. Moreno-Arribas, M.V.; Polo, M.C. Wine Chemistry and Biochemistry; Springer: New York, NY, USA, 2009.

48. Miranda-Lopez, R.; Libbey, L.M.; Watson, B.T.; McDaniel, M.R. Odor analysis of pinot noir wines from grapes of different maturities by a Gas chromatography-olfactometry technique (Osme). J. Food Sci. 1992, 57, 985-993. [CrossRef]

49. Kandylis, P.; Dimitrellou, D.; Lymnaiou, P.; Koutinas, A.A. Freeze-dried Saccharomyces cerevisiae cells immobilized on potato pieces for low-temperature wine-making. Appl. Biochem. Biotechnol. 2014, 173, 716-730. [CrossRef] [PubMed]

50. Kopsahelis, N.; Bosnea, L.; Bekatorou, A.; Tzia, C.; Kanellaki, M. Alcohol production from sterilized and non-sterilized molasses by Saccharomyces cerevisiae immobilized on brewer's spent grains in two types of continuous bioreactor systems. Biomass. Bioenergy 2012, 45, 87-94. [CrossRef]

51. Maiorella, B.L.; Blanch, H.W.; Wilke, C.R. Economic evaluation of alternative ethanol fermentation processes. Biotechnol. Bioeng. 1984, 26, 1003-1025. [CrossRef] [PubMed]

52. Tao, F.; Miao, J.Y.; Shi, G.Y.; Zhan, K.C. Ethanol fermentation by an acidtolerant Zymomonas mobilis under non-sterilized condition. Process Biochem. 2005, 40, 183-187. [CrossRef]

53. Ma, H.; Xing, Y.; Yu, M.; Wang, Q. Feasibility of converting lactic acid to ethanol in food waste fermentation by immobilized lactate oxidase. Appl. Energy 2014, 99, 89-93. [CrossRef]

54. Reynolds, A.; Cliff, M.; Ginard, B.; Kopp, T. Influence of fermentation temperature on composition and sensory properties of Semillon and Shiraz wines. Am. J. Enol. Vitic. 2001, 52, 3-6.

55. De Torres, C.; Díaz-Marotoa, M.C.; Hermosín-Gutiérrez, I.; Pérez-Coelloa, M.S. Effect of freeze-drying and oven-drying on volatiles and phenolics composition of grape skin. Anal. Chim. Acta 2010, 660, 177-182. [CrossRef] [PubMed]

56. Wines of Greece. Available online: https://winesofgreece.org/meet-the-grapes/grape-varieties/ (accessed on 28 February 2021).

57. Zamora, F. Dealcoholised Wines and Low-Alcohol Wines. In Wine Safety, Consumer Preference, and Human Health; Moreno-Arribas, M.V., Bartolomé Suáldea, B., Eds.; Springer International Publishing: Cham, Switzerland, 2016; pp. $163-182$. 